\title{
The no-touch saphenous vein graft in elderly coronary bypass patients with multiple comorbidities is a promising conduit to substitute the left internal thoracic artery
}

\author{
Ninos Samano, MD, PhD, ${ }^{\mathrm{a}}$ Håkan Geijer, $\mathrm{MD}, \mathrm{PhD},{ }^{\mathrm{b}}$ Lennart Bodin, $\mathrm{PhD},{ }^{\mathrm{c}}$ Mikael Arbeus, MD, \\ John D. Mannion, MD, ${ }^{\mathrm{d}}$ Michael Dashwood, $\mathrm{PhD},{ }^{\mathrm{e}}$ and Domingos Souza, $\mathrm{MD}, \mathrm{PhD}^{\mathrm{a}}$
}

\begin{abstract}
Objectives: We investigated the patency rates of no-touch saphenous vein grafts anastomosed to the left anterior descending artery compared with the left internal thoracic artery. Further, we compared the patency of no-touch vein grafts to the left anterior descending artery with the patency of no-touch vein grafts to other coronary arteries.
\end{abstract}

Methods: Of 2635 consecutive patients undergoing coronary artery bypass grafting between 2003 and 2008, $168(6.3 \%)$ were given at least a saphenous vein graft to the left anterior descending artery to avoid harvesting complications in high-risk patients or in response to a left internal thoracic artery injury. A total of 97 patients were consecutively included after informed consent. A clinical examination and computed tomography angiography were performed on 91 patients at a mean of 6 (4-9) years.

Results: The mean age of patients was $75.6 \pm 8.5$ years. Postoperatively, $88.7 \%$ of patients (86/97) were free of angina. The 91 examined patients had 163 grafts with 286 distal anastomoses. Crude patency, according to distal anastomoses, was $94.4 \%$ (270/286). The patency of single versus sequential no-touch vein grafts to the left anterior descending artery was 98\% (50/51) versus $92.5 \%$ (37/40). The total patency rate was 95.6\% (87/91), similar to the reported patency rate for the left internal thoracic artery. The no-touch grafts to the left anterior descending artery versus other coronaries had a patency of $95.6 \%$ (87/91) versus $93.8 \%$ (183/195), a high similarity confirmed by an equivalence analysis.

Conclusions: In elderly coronary bypass patients with multiple comorbidities, a no-touch saphenous vein graft is a promising substitute for the left internal thoracic artery. (J Thorac Cardiovasc Surg 2017;154:457-66)

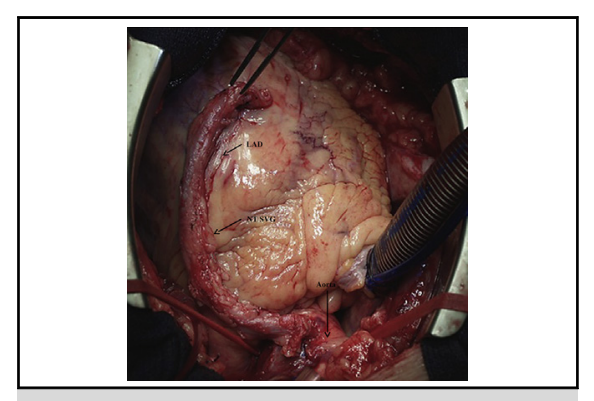

An NT SVG to the LAD.

Central Message

In elderly coronary bypass patients with multiple comorbidities, the NT SVG is a promising substitute for the LITA.

\section{Perspective}

The NT SVG harvesting technique was demonstrated to be an effective approach in prevention of late vein graft failure. The NT SVG should be included in the arsenal of conduits in $\mathrm{CABG}$.

See Editorial Commentary page 467.

See Editorial page 455.
Ischemic heart disease is currently the leading cause of death globally and is expected to account for $14.2 \%$ of all deaths by $2030 .{ }^{1}$ Coronary artery bypass grafting (CABG) is among the most common operations performed in the world ${ }^{2}$ and is the best treatment for advanced ischemic heart disease. $^{3-5}$

\footnotetext{
From the Departments of ${ }^{\mathrm{a}}$ Cardiothoracic and Vascular Surgery and ${ }^{\mathrm{b}}$ Radiology, Faculty of Medicine and Health, Örebro University, Örebro, Sweden; ${ }^{\mathrm{c} I n t e r v e n t i o n ~ a n d ~}$ Implementation Research, Institute of Environmental Medicine, Karolinska Institute, Stockholm, Sweden; ${ }^{\mathrm{d} D e p a r t m e n t}$ of Surgery, Bayhealth Medical Center, Dover, Del; and ${ }^{\mathrm{e}}$ Surgical and Interventional Sciences, Royal Free Hospital Campus, University College Medical School, London, United Kingdom.

This study was approved by the Regional Ethical Review Board in Uppsala (Dnr: 2011/076) and supported by Örebro County Council through the regional research board and Nyckelfonden (Grant No. 11-029).
}

Graft patency in CABG is a major determinant of clinical prognosis, measured by reoperation rates and long-term survival. ${ }^{6}$ The decision on what conduit to use to bypass the left anterior descending (LAD) artery is a settled issue. ${ }^{3,4,7}$ Since the definitive article by Loop and colleagues ${ }^{8}$ in 1986, surgeons have strived to use a left internal thoracic

Clinical Trial Registration: NCT02339857 and the Research and Development registry in Sweden: 102881, 30-03-2012.

Received for publication Feb 15, 2016; revisions received Feb 9, 2017; accepted for publication March 7, 2017; available ahead of print April 19, 2017.

Address for reprints: Ninos Samano, MD, PhD, Department of Cardiothoracic and Vascular Surgery, Örebro University Hospital, SE-70185 Örebro, Sweden (E-mail: ninos.samano@regionorebrolan.se).

$0022-5223 / \$ 36.00$

Copyright $(C) 2017$ by The American Association for Thoracic Surgery

http://dx.doi.org/10.1016/j.jtcvs.2017.03.048 


\section{Abbreviations and Acronyms \\ $\mathrm{CABG}=$ coronary artery bypass grafting \\ $\mathrm{CI}=$ confidence interval \\ COPD $=$ chronic obstructive pulmonary disease \\ CTA $=$ computed tomography angiography \\ euroSCORE $=$ European System for Cardiac Operative Risk Evaluation \\ LAD $=$ left anterior descending \\ LITA $=$ left internal thoracic artery \\ NT $\quad=$ no-touch \\ SVG $=$ saphenous vein graft}

Scanning this QR code will take you to supplemental tables and video for this article.

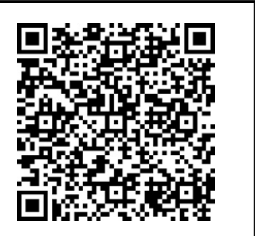

artery (LITA) to bypass the LAD to capture the benefits of greater patency than achieved with conventional saphenous vein grafts (SVGs), and thus improve survival. Since the LITA as a conduit choice for the LAD was made a quality issue by the Society of Thoracic Surgeons, LITA use in the United States has increased, from $87.7 \%$ in 2000 to $94.7 \%$ in $2009 .{ }^{9}$ However, given that CABG is a common operation, the $5.3 \%$ of patients who do not receive a LITA are a large number of patients.

There is still discussion about the best choice of conduit for the LAD when a LITA is injured during harvesting or when a surgeon wants to avoid LITA harvesting because of severe frailty, obesity, chronic obstructive pulmonary disease (COPD), intermediate LAD stenosis, or other reasons that place the patient in a particularly high-risk category. In these situations, multiple other conduits are available, such as the radial artery or the right internal thoracic artery, yet none are ideal, and their use sometimes presents difficult technical challenges.

An improved saphenous vein conduit might simplify a complex CABG procedure and would be valuable if the patency was similar to that of the LITA. A conventional harvest causes severe saphenous vein trauma. When SVGs are stripped from the surrounding tissue, spasm is induced, which is overcome by dilatation with normal saline or blood. Mechanical dilatation and suboptimal preservation solution cause vessel wall damage $^{10}$ and may explain the higher incidence of early graft occlusion, progressive intimal hyperplasia, atherosclerosis, and late graft occlusion seen in conventional SVGs. ${ }^{11}$
Since the beginning of the 1990s, we have been using a technique for SVG preparation whereby the vein is harvested with a pedicle of surrounding tissue intact and no dilatation is used, called the "no-touch [NT] technique" (Video 1). ${ }^{12}$ This technique provides a superior patency rate, ${ }^{13-15}$ preserved left ventricular function, ${ }^{16}$ and a better clinical outcome ${ }^{17}$ compared with conventional harvesting, in both the short and the long term. Above all, in a previous study by our group, the NT SVG patency to non-LAD targets was comparable to that of LITA to LAD at a mean time of 16 years postoperatively. ${ }^{15}$ With this experience, it seemed reasonable to assume that the NT SVG would achieve an equal, if not greater, patency rate if anastomosed to the LAD.

The primary aim of the present study was to document the patency rates and clinical outcomes in patients with NT SVGs placed to the LAD at a mean of 6 years postoperatively. The secondary aim was to compare the patency of the NT vein grafts placed to the LAD with that of NT vein grafts placed to non-LAD territories.

\section{MATERIALS AND METHODS}

\section{Study Design}

In this observational cohort study, ${ }^{18} 2635$ consecutive patients who had undergone CABG between 2003 and 2008 were screened for eligibility. A total of 168 patients were consecutively identified as having received an SVG to the LAD (Figure 1) and having been operated at the Department of Cardiothoracic and Vascular Surgery, Örebro University Hospital, Örebro, Sweden. Our local registry and patient files were used to identify this group. Baseline data were retrieved retrospectively from our local registry. The follow-up was performed at a mean of 6 years postoperatively. The study was approved by the Regional Ethical Review Board in Uppsala. Patients were included at follow-up after informed consent had been obtained.

All surviving patients who had received an NT SVG, as a single or a sequential graft, to the LAD were offered a clinical assessment and a computed tomography angiography (CTA). Exclusion criteria were allergy to contrast media, impaired renal function, or inability to participate in the study according to protocol. A total of 97 patients were enrolled in the

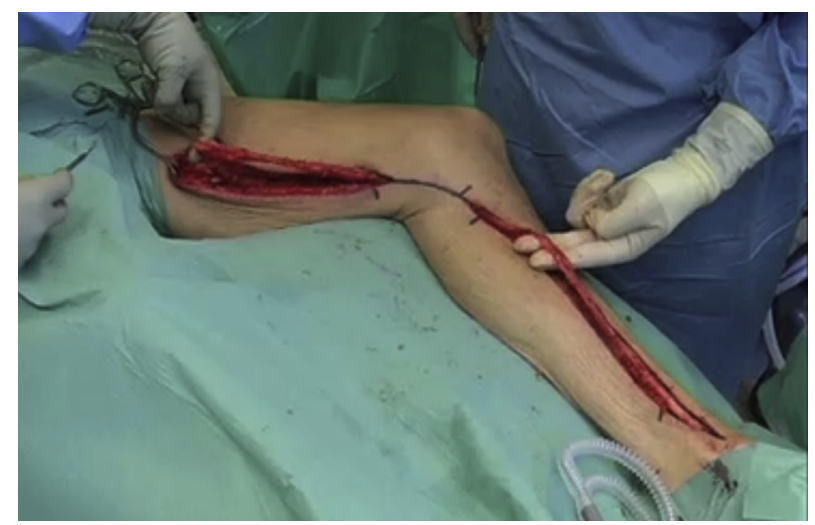

VIDEO 1. Surgical notes on the NT SVG harvesting technique in CABG. Video available at: http://www.jtcvsonline.org/article/S0022-5223(17) 30558-5/addons. 


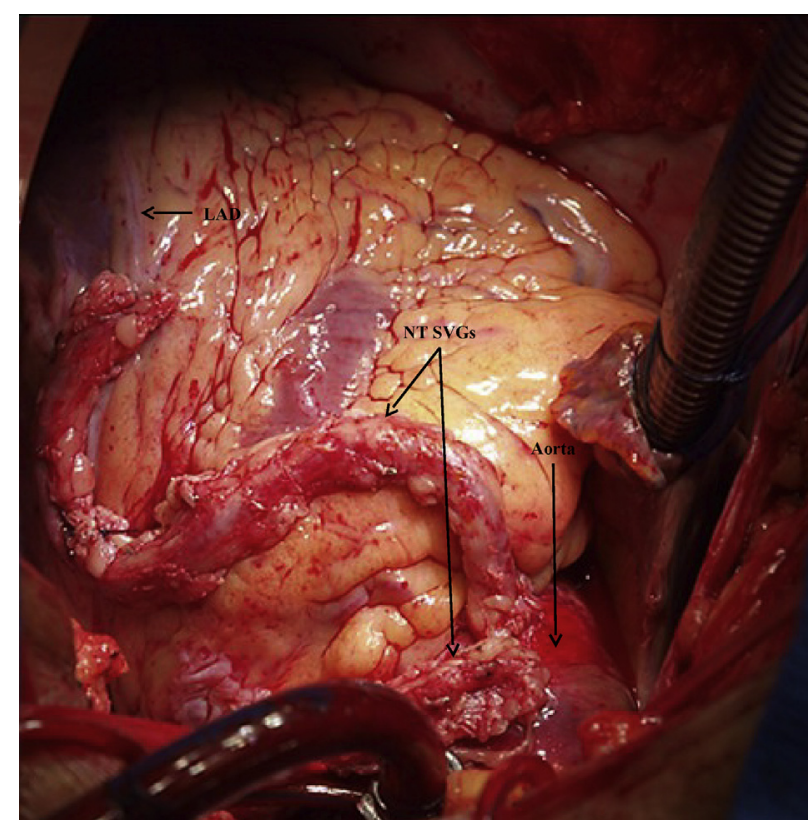

FIGURE 1. NT SVG to the LAD artery. $N T S V G$, No-touch saphenous vein graft; $L A D$, left anterior descending.

study, and 91 of them underwent 1 CTA. For those who had died before the follow-up, the causes of death were established from the Swedish death registry and patient files.

\section{Clinical Evaluation}

The clinical evaluation included history, physical examination, and blood works (complete blood count, renal function, and lipid profile).

\section{Angiography}

CTA was selected because of the less-invasive nature of this technique and its reliability in identifying graft occlusion. ${ }^{19}$ The electrocardiogramgated CTA examinations were performed with a SOMATOM Flash, dual-source computed tomography scanner (Siemens, Erlangen, Germany). All subjects received $0.25 \mathrm{mg}$ nitroglycerin sublingually, and those with a heart frequency of more than 70 beats/min and no contraindications also were given up to $10 \mathrm{mg}$ metoprolol intravenously before the examination. Sixty to $70 \mathrm{~mL}$ of contrast media (Iomeron $400 \mathrm{mg} / \mathrm{mL}$; Bracco, Milan, Italy) was administered with a pressure injector at a flow rate of $6 \mathrm{~mL} / \mathrm{s}$, followed by a bolus of $60 \mathrm{~mL}$ saline.

The images were reviewed at a Siemens Syngo Multi-Modality Workplace workstation. All images were reviewed by a thoracic radiologist. When possible, the studies were compared with reports and images from previous coronary angiographies. A graft was judged as occluded when it was not opacified by contrast media. The origin of occluded grafts was readily visible in the anterior ascending aorta. The native coronary arteries were not evaluated.

\section{Statistical Methods}

Statistical analysis was performed on data from 97 patients, 91 of whom were available for angiographic analysis. These 91 patients had 163 grafts with 286 distal anastomoses, which means that each patient constitutes a cluster of statistically dependent observations regarding patency for anastomoses to the LAD and non-LAD targets. For this reason, the analysis of patency at the level of distal anastomoses had to include adjustments for intrapatient correlations to obtain statistical validity in estimates and confidence intervals (CIs). Therefore, the model was a generalized linear latent and mixed model ${ }^{20}$ for binomial data (with 2 possible outcomes, "yes" or "no," for patency) with an identity link function. With the identity link function, estimates of the difference in percentage of patency between LAD and non-LAD anastomoses can be directly inferred from the results of the analysis. For calculation of CIs and $P$ values, the intrapatient correlation, with 2 to 6 anastomoses per patient, was accounted for in the model by treating patients as separate clusters and applying cluster-specific formulas for CIs and $P$ values. The model included, in addition to the factor LAD versus non-LAD anastomoses, a temporal component, that is, time from the date of surgery to the date of angiographic assessment, expressed in years. Comparisons of basic patient characteristics were performed using chi-square tests for categoric data and $t$ tests for continuous data. All other CIs and $P$ values are from the generalized linear latent and mixed model. STATA release 14 (StataCorp LP, College Station, Tex; www.stata.com) and SPSS version 22 (SPSS Inc, Chicago, Ill) were used in the computations.

Patency comparisons between NT SVGs to LAD and NT SVGs with non-LAD targets were done with the aim of assessing noninferiority and equivalence of the NT technique for these 2 kinds of anastomoses. The approach recommended by Fleming ${ }^{21}$ and Christensen ${ }^{22}$ was used. Results are shown as CIs for the differences in patency rates between the investigated anastomoses. The margins of equivalence and noninferiority were set to \pm 10 percentage points. Through these CIs, possible equivalences between the patency of LAD and the different non-LAD anastomoses can be visualized. CIs that fall completely within the margins of equivalence show no rejection of the equivalence hypothesis; CIs that include zero, but extend outside the margins of equivalence are inconclusive (because of low statistical power for a small dataset), and CIs that do not include zero reject the equivalence hypothesis. The confidence level was set to $90 \%$; therefore, equivalence is evaluated at this level and noninferiority can be deduced from the lower $90 \%$ CI level, referred to as 1 -sided $95 \%$ CI for noninferiority.

\section{RESULTS}

A total of 2635 patients underwent CABG between 2003 and 2008 and were examined for eligibility. A total of 168 patients $(168 / 2635 ; 6.3 \%)$ received an SVG to the LAD. Of these, $126(126 / 2635 ; 4.8 \%)$ received a planned SVG to the LAD. In the remaining 42 patients $(42 / 2635 ; 1.6 \%)$, the LITA was damaged during harvesting, had low free flow rates, or was too short to reach the LAD and was consequently anastomosed to non-LAD targets.

The all-cause death rate was $20.2 \%(34 / 168)$ at the time of the follow-up. Cardiac-related deaths occurred in $7.7 \%$ of patients (13/168), with heart failure, acute myocardial infarction, and cardiac arrhythmias being major causes. Noncardiac-related deaths occurred in $12.5 \%$ of patients (21/168). Cancer and infections constituted the majority of causes, but some of the deaths were due to renal failure, cerebrovascular lesion, liver cirrhosis, pulmonary embolism, and complications after femur fractures.

Figure 2 shows the screening and inclusion process. A total of 97 patients were included in the clinical evaluation, and 91 patients underwent CTA. Baseline and perioperative clinical characteristics are shown in Table 1 . The patients are divided into 2 groups: no LITA harvested and LITA harvested, but the LITA was not used or it was anastomosed to non-LAD target coronaries. Patients in the no LITA 


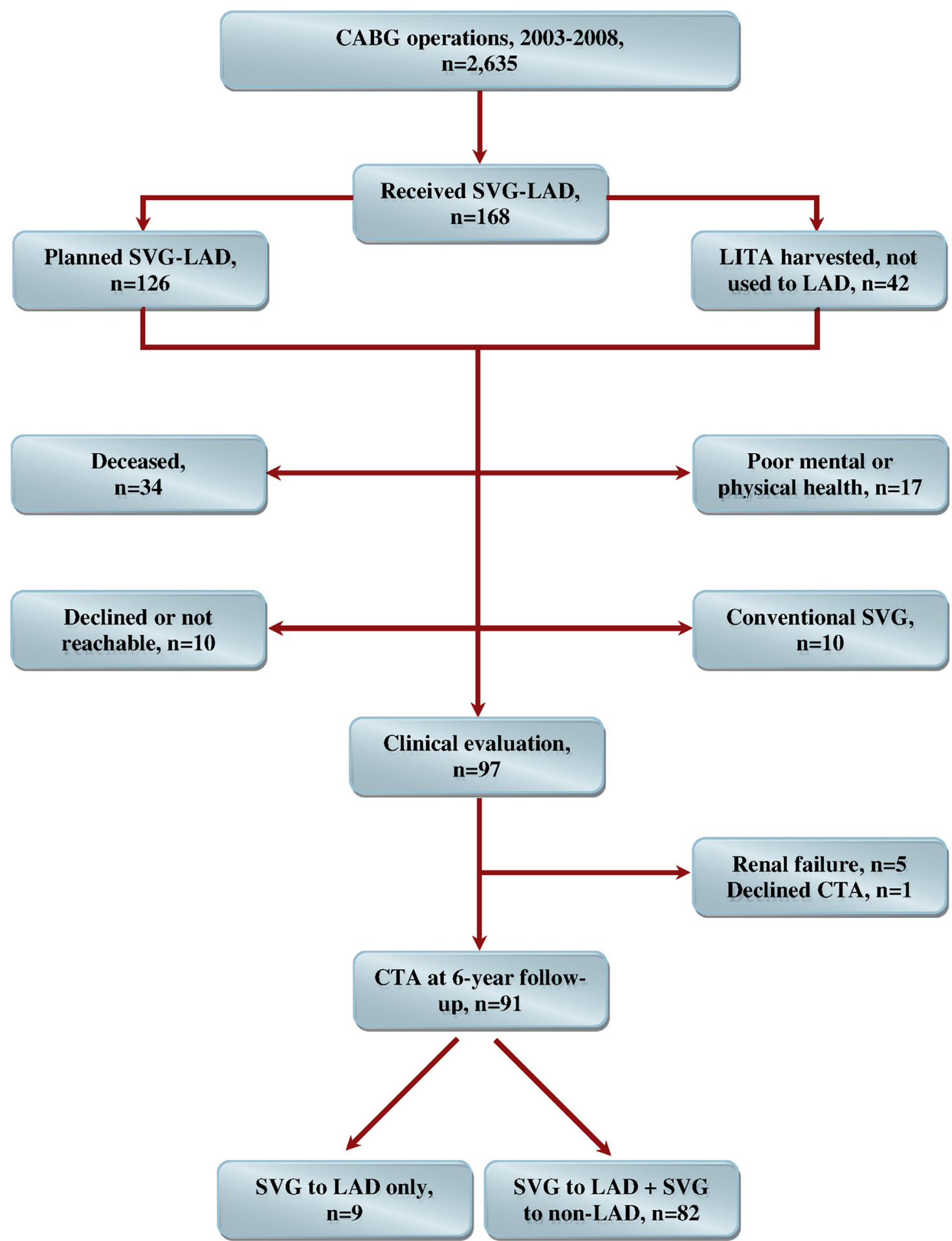

FIGURE 2. Flow chart of screening and patient inclusion. $C A B G$, Coronary artery bypass grafting; $S V G$, saphenous vein graft; $L A D$, left anterior descending artery; LITA, left internal thoracic artery; CTA, computed tomography angiography.

harvested group were older $(P=.017)$, had a lower ejection fraction $(P=.029)$, and had higher risk scores (additive European System for Cardiac Operative Risk Evaluation score [euroSCORE] $6.63 \pm 3.5$ vs $4.5 \pm 2.7, P=.001$; and Higgins score $4.3 \pm 3.5$ vs $2.6 \pm 2.2, P=.004)$ compared with patients in the LITA harvested group. Patients undergoing a combined procedure consisted of $33.3 \%(42 / 126)$ of the no LITA harvested group versus 
TABLE 1. Baseline and perioperative clinical characteristics

\begin{tabular}{|c|c|c|c|}
\hline Patient characteristics & No LITA harvested group & LITA harvested group & $P$ value \\
\hline No. of patients & 126 & 42 & \\
\hline Mean age, $y, \pm S D$ & $72.4 \pm 7.7$ & $68.4 \pm 9.5$ & .017 \\
\hline Male, n/total N (\%) & $94 / 126(74.6)$ & $34 / 42(81)$ & .403 \\
\hline Body mass index, mean $\pm \mathrm{SD}$ & $27.3 \pm 5.2$ & $26.1 \pm 4$ & .158 \\
\hline Smoking (past and present), $\mathrm{n} /$ total N (\%) & $70 / 126(55.6)$ & $25 / 42(59.5)$ & 653 \\
\hline Hypertension, n/total N (\%) & $77 / 126(61.1)$ & $23 / 42(54.8)$ & .468 \\
\hline Diabetes mellitus, $\mathrm{n} /$ total $\mathrm{N}(\%)$ & $40 / 126(31.7)$ & $12 / 42(28.6)$ & .700 \\
\hline COPD, n/total N (\%) & 20/126 (15.9) & $2 / 42(4.8)$ & .065 \\
\hline PCI, n/total N (\%) & $15 / 126(11.9)$ & $6 / 42(14.3)$ & 666 \\
\hline Previous cardiac surgery, n/total N (\%) & 9/126 (7.1) & $2 / 42(4.8)$ & .589 \\
\hline \multicolumn{4}{|l|}{ Coronary vessel disease, $\mathrm{n} /$ total $\mathrm{N}(\%)$ : } \\
\hline 1-vessel disease & $11 / 126(8.7)$ & $2 / 42(4.8)$ & .404 \\
\hline 2-vessel disease & $33 / 126(26.2)$ & $10 / 42(23.8)$ & .759 \\
\hline 3-vessel disease & $82 / 126(65.1)$ & $30 / 42(71.4)$ & .450 \\
\hline \multicolumn{4}{|l|}{ NYHA class, $\mathrm{n} /$ total $\mathrm{N}(\%)$ : } \\
\hline I & 0 & $1 / 42(2.4)$ & .730 \\
\hline II & 24/126 (19) & $6 / 42(14.3)$ & \\
\hline III & $77 / 126(61.1)$ & $30 / 42(71.4)$ & .228 \\
\hline IV & $25 / 126(19.8)$ & $5 / 42(11.9)$ & .245 \\
\hline \multicolumn{4}{|l|}{ Left ventricular function, $\mathrm{n} /$ total $\mathrm{N}(\%)$ : } \\
\hline Good $(\mathrm{EF}>50 \%)$ & $79 / 126(62.7)$ & $34 / 42(81)$ & .029 \\
\hline Moderate (EF 31\%-50\%) & $23 / 126(18.3)$ & $4 / 42(9.5)$ & .182 \\
\hline Poor (EF $21 \%-30 \%$ ) & $10 / 126(7.9)$ & $2 / 42(4.8)$ & .489 \\
\hline Very poor $(\mathrm{EF}<20 \%)$ & $14 / 126(11.1)$ & $2 / 42(4.8)$ & .225 \\
\hline euroSCORE, $*$ mean $\pm \mathrm{SD}$ & $6.63 \pm 3.5$ & $4.5 \pm 2.7$ & .001 \\
\hline Higgins score,$\nmid$ mean $\pm \mathrm{SD}$ & $4.3 \pm 3.5$ & $2.6 \pm 2.2$ & .004 \\
\hline $\mathrm{CABG}+$ other cardiac procedures & $42 / 126(33.3)$ & $5 / 42(11.9)$ & .007 \\
\hline Operation time $(\mathrm{min})$, mean $\pm \mathrm{SD}$ & $265.4 \pm 76.5$ & $241.6 \pm 55.6$ & .064 \\
\hline ECC time $(\min )$, mean $\pm \mathrm{SD}$ & $135.2 \pm 48.7$ & $109.6 \pm 34.1$ & .001 \\
\hline Aortic crossclamp (min), mean $\pm \mathrm{SD}$ & $89.1 \pm 39.8$ & $67.2 \pm 28.2$ & .001 \\
\hline Red blood cell transfusion, $\mathrm{n} /$ total N (\%) & $84 / 126(66.7)$ & $27 / 42(64.3)$ & .778 \\
\hline Intensive care unit time $(h)$, mean $\pm \mathrm{SD}_{\ddagger}^{\ddagger}$ & $41 \pm 62.0$ & $25.4 \pm 26.6$ & .035 \\
\hline Atrial fibrillation, $\mathrm{n} /$ total $\mathrm{N}(\%)$ & $49 / 126(38.9)$ & $8 / 42(19)$ & .019 \\
\hline Cerebrovascular accidents, $\mathrm{n} /$ total $\mathrm{N}(\%)$ & 4/126 (3.2) & $1 / 42(2.4)$ & .793 \\
\hline Reoperation for bleeding, n/total N (\%) & $8 / 126(6.3)$ & $3 / 42(7.1)$ & .857 \\
\hline Reoperation for mediastinitis, n/total N (\%) & 2/126 (1.6) & $1 / 42(2.4)$ & .737 \\
\hline Deceased during the 6-y follow-up, n/total N (\%) & $29 / 126(23.0)$ & $5 / 42(11.9)$ & .121 \\
\hline
\end{tabular}

LITA, Left inferior thoracic artery; SD, standard deviation; COPD, chronic obstructive pulmonary disease; PCI, percutaneous coronary intervention; NYHA, New York Heart Association; $E F$, ejection fraction; $C A B G$, coronary artery bypass grafting; $E C C$, extracorporeal circulation; $L A D$, left anterior descending; $S V G$, saphenous vein graft. *euroSCORE. Data missing for 16 patients ( 8 per group). $\dagger$ Stratification of morbidity and mortality outcome by preoperative risk factors in patients undergoing CABG. Data missing for 6 patients ( 3 per group). †Data missing for 16 patients.

$11.9 \%(5 / 42)$ of the LITA harvested group $(P=.007)$. These differences in the groups could explain the longer aortic crossclamp and extracorporeal circulation time in the no LITA harvested group.

The reasons reported by the operating surgeons for patients not receiving a LITA graft to the LAD were single factor in $30.9 \%$ of patients $(52 / 168)$ and multifactorial $(2-5$ factors) in $69.1 \%$ of patients (116/168). The single factors given were intermediate LAD stenosis, surgical damage, low flow, subclavian stenosis, and radiation injury. The composite factors included age 75 years or more, diabetes mellitus, obesity, COPD, heart failure, and CABG plus another procedure.

\section{Clinical Evaluation}

Clinical characteristics at a mean of 6 (4-9) years are shown in Table 2. A total of 97 patients were included in the clinical follow-up at a mean age of $75.6 \pm 8.5$ years. Altogether, $88.7 \%$ of patients (86/97) were free of angina postoperatively, $44(44 / 86 ; 51.2 \%)$ of whom had New York Heart Association class I. Many of the remaining patients had comorbidities, such as joint pain, intermittent claudication, and stroke, which lowered their functional class. In our follow-up, $93.8 \%$ of patients (91/97) were receiving antiplatelet therapy and $89.7 \%$ of patients $(87 / 97)$ were being treated with statins. 
TABLE 2. Clinical characteristics at 6-year follow-up

\begin{tabular}{|c|c|}
\hline Patient characteristics & \\
\hline Patients, $\mathrm{n}$ & 97 \\
\hline Mean age, $y, \pm S D$ & $75.6 \pm 8.5$ \\
\hline Male, n/total N (\%) & 78/97 (80.4) \\
\hline Body mass index, mean $\pm \mathrm{SD}$ & $27.6 \pm 4.9$ \\
\hline Heredity of ischemic heart disease, $\mathrm{n} /$ total $\mathrm{N}(\%)$ & $46 / 97(47.4)$ \\
\hline Smoking (past and present), n/total N (\%) & 48/97 (49.5) \\
\hline Hypertension, n/total N (\%) & 69/97 (71.1) \\
\hline Diabetes mellitus, n/total N (\%) & 38/97 (39) \\
\hline Hyperlipidemia, n/total N (\%) & 95/97 (97.9) \\
\hline $\mathrm{BNP}>150 \mathrm{ng} / \mathrm{L}, \mathrm{n} /$ total N $(\%)$ & $42 / 97(43.3)$ \\
\hline Serum cholesterol $(\mathrm{mmol} / \mathrm{L})$, mean $\pm \mathrm{SD}$ & $4.4 \pm 1.2$ \\
\hline Serum LDL (mmol/L), mean \pm SD & $2.3 \pm 0.8$ \\
\hline Serum HDL $(\mathrm{mmol} / \mathrm{L})$, mean $\pm \mathrm{SD}$ & $1.2 \pm 0.4$ \\
\hline Beta-blockers, n/total N (\%) & 75/97 (77.3) \\
\hline Calcium inhibitors, n/total N (\%) & 24/97 (24.7) \\
\hline ASA, n/total N (\%) & $82 / 97(84.5)$ \\
\hline Warfarin, n/total N (\%) & 13/97 (13.4) \\
\hline Clopidogrel, n/total N (\%) & $8 / 97(8.2)$ \\
\hline Statins, n/total N (\%) & $87 / 97(89.7)$ \\
\hline Nitrates, n/total N (\%) & 18/97 (18.6) \\
\hline Diuretics, $\mathrm{n} /$ total N (\%) & $36 / 97(37.1)$ \\
\hline ACE inhibitors or AII blockers, n/total N (\%) & $66 / 97(68)$ \\
\hline Peroral diabetic medication only, n/total N (\%) & $11 / 38^{*}(11.3)$ \\
\hline Insulin-dependent diabetes, n/total N (\%) & $10 / 38(10.3)$ \\
\hline Peroral and insulin diabetic medication, $\mathrm{n} /$ total $\mathrm{N}(\%)$ & $14 / 38(14.4)$ \\
\hline Sinus rhythm, n/total N (\%) & $71 / 97(73.2)$ \\
\hline Atrial fibrillation, n/total N (\%) & 18/97 (18.6) \\
\hline Permanent pacemaker, n/total N (\%) & $8 / 97(8.3)$ \\
\hline Angina-free patients, n/total N (\%) & $86 / 97(88.7)$ \\
\hline \multicolumn{2}{|l|}{ NYHA class, n/total N $(\%)$ : } \\
\hline I & $44 / 86(51.2)$ \\
\hline II & $17 / 86(19.8)$ \\
\hline III & $24 / 86(27.9)$ \\
\hline IV & $1 / 86(11.7)$ \\
\hline Recurrent angina, n/total N (\%) & 11/97 (11.3) \\
\hline \multicolumn{2}{|l|}{ CCS angina class, $\mathrm{n} /$ total $\mathrm{N}(\%)$ : } \\
\hline I & 2/11 (18.2) \\
\hline II & $3 / 11(27.3)$ \\
\hline III & $6 / 11(54.5)$ \\
\hline IV & 0 \\
\hline Percutaneous coronary intervention, n/total N (\%) & $2 / 97(2.1)$ \\
\hline Redo CABG, n/total N (\%) & $1 / 97(1.0)$ \\
\hline \multicolumn{2}{|l|}{ Vein harvesting site assessment } \\
\hline No symptoms, n/total N (\%) & 90/97 (92.8) \\
\hline Numbness, n/total N (\%) & $6 / 97(6.2)$ \\
\hline Pain, n/total N (\%) & $1 / 97(1.0)$ \\
\hline euroSCORE, $\uparrow$ mean \pm SD & $6.01 \pm 3.4$ \\
\hline
\end{tabular}

$\overline{S D \text {, Standard deviation; } B N P \text {, brain natriuretic peptide; } L D L \text {, low-density lipoprotein; }}$ $H D L$, high-density lipoprotein; $A S A$, acetylsalicylic acid; $A C E$, angiotensinconverting enzyme; NYHA, New York Heart Association; $C A B G$, coronary artery bypass grafting; CCS, Canadian Cardiovascular Society; euroSCORE, European System for Cardiac Operative Risk Evaluation. *Three patients had diet-treated diabetes. †Baseline euroSCORE for 91 patients who underwent CTA.

Recurrent angina occurred postoperatively in $11.3 \%$ of patients (11/97). One patient underwent a further CABG because of stenosis in previously nongrafted coronary arteries, and 2 patients underwent percutaneous coronary intervention with stenting, 1 to the native intermediate branch (previously grafted and occluded) and 1 to an SVG anastomosed to the posterior descending artery. Eight patients presented with angina at follow-up, 5 of whom had patent SVGs. These 8 patients were referred to a cardiologist for further evaluation.

\section{Angiographic Evaluation}

The majority of patients received an NT SVG to the LAD, as a single or sequential graft, together with sequential NT SVGs to the other target coronaries (Figure 3).

Ninety-one patients underwent CTA (baseline euroSCORE 6.01). The total number of NT SVGs examined with CTA was 163 . These were made up of 77 single, 51 double, 27 triple, and 4 quadruple sequential grafts, and 4 Y-composite grafts. Eight LITAs were used, 4 anastomosed to marginal branches, 3 anastomosed to diagonal branches, and 1 anastomosed to the distal LAD.

Patency is reported according to distal anastomoses. The total number of distal anastomoses for the NT SVGs was 286. The distribution of NT SVG and LITA patency, based on the number of distal anastomoses and target coronary arteries, is shown in Table 3. Table E1 shows the stratification of SVG patency according to the number of years between surgery and angiographic assessment.

Total patency was $94.4 \%$ (270/286). The patency of single and sequential NT SVGs to the LAD was $98 \%(50 / 51)$ versus $92.5 \%$ (37/40); consequently, NT SVGs to the LAD had a total patency of $95.6 \%$ (87/91). This is comparable to the reported patency rates for LITA to the LAD (Table E2 shows some of the major trials reporting patency of LITA and SVG to the LAD). The average patency rate for LITA to the LAD, adjusting for the number of patients in each of these studies, is $94.9 \%$. Including only those studies that span 5.0 to 6.6 years gives an average patency of $96.0 \%$.

The NT SVGs to non-LAD and LAD targets had a total patency of $93.8 \%(183 / 195)$ versus $95.6 \%$ (87/91), difference $-2.6 \%$ units ( $95 \% \mathrm{CI},-7.4$ to 2.1$), P=.28$ (Table E3). Thus, these figures are similar and were subjected to an equivalence analysis performed with NT SVGs to the LAD (reference) and NT SVGs to non-LAD targets for comparison. The $90 \%$ CIs are all within the \pm 10 percentage point margin determined a priori to indicate equivalence in patency between these grafts (Figure 4). In particular, the lower limit formally states that an NT SVG to a non-LAD vessel is not inferior to an NT SVG to the LAD at the $95 \%$ confidence level. ${ }^{21,22}$ Finally, the patency of all single and all sequential NT SVGs was $94.8 \%$ (73/77) and 94.3\% (197/209), respectively.

Attrition or loss to follow-up is a potential problem in longitudinal studies. A total of 168 patients received an SVG to the LAD (Figure 2), and at the clinical evaluation there were 97 patients available. A total of 71 patients 


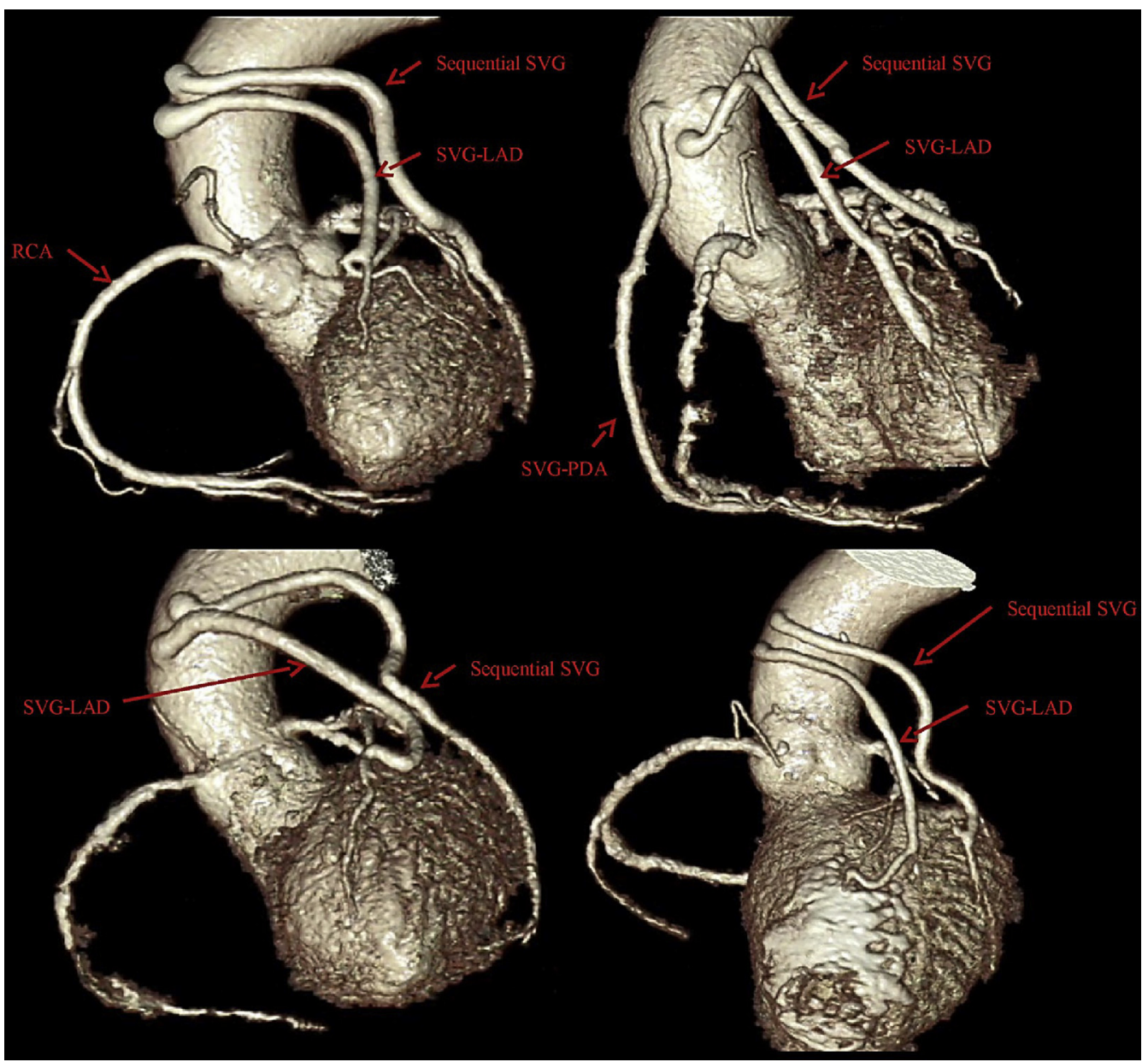

FIGURE 3. NT SVGs to different coronary targets in 4 different patients. $S V G$, Saphenous vein graft; $L A D$, left anterior descending artery; $R C A$, right coronary artery; $P D A$, posterior descending artery.

were lost for the clinical evaluation. To examine a possible effect of selection bias, age and euroSCORE were selected as factors that (1) showed few missing values (if any) at the clinical evaluation, (2) showed differences in baseline values between the 2 groups of included and not included patients, and (3) might influence graft patency. Therefore, the analysis of all available distal anastomoses was supplemented with analyses within strata of age $(<71$ vs $\geq 71$ years) and euroSCORE ( $\leq 5$ vs $>5$ score points). These results are shown in Table E3, and the differences in patency from SVGs to the LAD in the strata are only marginally different compared with those of the overall comparison. Thus, age and euroSCORE, which influence attrition, do not seem to affect the patency comparison to any large extent, although the possibility of a selection bias cannot be completely excluded.

The occluded SVGs were 4 single grafts, 1 totally occluded triple graft, 1 totally occluded double sequential graft, 2 partially occluded triple grafts, 2 partially occluded double sequential grafts, and 2 partially occluded Y-composite grafts. Fifteen of the 16 occluded distal anastomoses were placed to target vessels less than $2 \mathrm{~mm}$ in diameter. Only 1 LITA anastomosed to a marginal artery was occluded.

TABLE 3. Distribution of conduit patency by number of distal anastomoses and target coronary arteries

\begin{tabular}{|c|c|c|c|c|}
\hline Target coronary arteries (n) & $\begin{array}{c}\text { All SVGs: } \\
\text { Patent/total }(\%)\end{array}$ & $\begin{array}{c}\text { Single SVGs: } \\
\text { Patent/total (\%) }\end{array}$ & $\begin{array}{c}\text { Sequential SVGs: } \\
\text { Patent/total ( } \%)\end{array}$ & $\begin{array}{c}\text { LITA: } \\
\text { Patent/total (\%) }\end{array}$ \\
\hline $\operatorname{LAD}(\mathrm{n}=91)$ & $87 / 91(95.6)$ & $50 / 51(98.0)$ & $37 / 40(92.5)$ & $1 / 1(100)^{*}$ \\
\hline Diagonal artery $(\mathrm{n}=50)$ & 49/50 (98.0) & $1 / 1(100)$ & 48/49 (97.9) & $3 / 3(100)$ \\
\hline Marginal artery $(\mathrm{n}=93)$ & $85 / 93(91.4)$ & $6 / 7(85.7)$ & 79/86 (91.9) & $3 / 4(75)$ \\
\hline Right coronary artery $(\mathrm{n}=52)$ & $49 / 52(94.2)$ & $16 / 18(88.9)$ & $33 / 34(97.1)$ & \\
\hline All non-LAD coronary arteries $(n=195)$ & $183 / 195(93.9)$ & $23 / 26(88.5)$ & $160 / 169(94.7)$ & \\
\hline
\end{tabular}

SVG, Saphenous vein graft; LITA, left internal thoracic artery; LAD, left anterior descending. *LITA anastomosed to distal LAD 


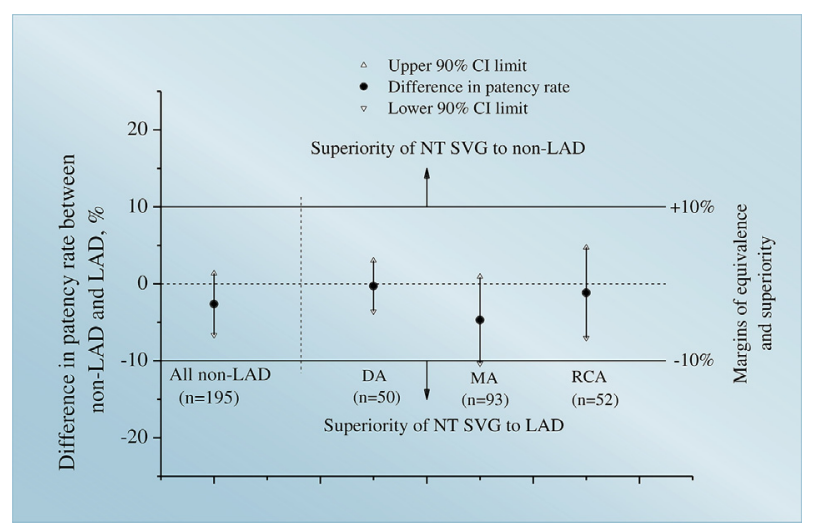

FIGURE 4. Differences in patency between NT SVGs to the LAD (reference) and NT SVGs to non-LAD targets. The 3 CIs and the 10 percentage point margin are the basis for comparing SVGs with different target coronary arteries with respect to potential equivalence and noninferiority. Analysis by generalized linear latent and mixed models (see text). LAD, Left anterior descending; $C I$, confidence interval; $N T S V G$, no-touch saphenous vein graft; $D A$, diagonal artery; $M A$, marginal artery; $R C A$, right coronary artery.

\section{DISCUSSION}

The key feature of this study is that in elderly patients with multiple comorbidities, NT SVGs placed to the LAD had a high patency similar to that reported for a LITA to the LAD at a mean of 6 years postoperatively. The selection of patients was not randomized, but most of those receiving the NT vein graft to the LAD had a higher risk of unfavorable outcome in terms of patency. The excellent clinical and patency results in these patients suggest that an arterial graft may not be necessary to replace a LITA damaged during harvesting or that a LITA is always required in a patient with extensive comorbidities, particularly when the degree of LAD stenosis is $75 \%$ or less, as recently shown by Harskamp and colleagues. ${ }^{23}$ Likewise, Goldman and colleagues $^{24}$ report a patency of approximately $87.5 \%$ for LITA to the LAD compared with $75 \%$ for conventional SVGs to the LAD at 6 years postoperatively. ${ }^{24}$ Tatoulis and colleagues ${ }^{25}$ report a patency rate of $97.1 \%$ for LITA to the LAD and $60.2 \%$ for conventional SVGs to the LAD at a mean of 6.3 years. In this study, we have shown a patency rate of $98 \%$ for single NT SVGs to the LAD.

A LITA to the LAD remains the gold standard in $\mathrm{CABG}^{7,26}$ and should be used provided that there is no contraindication to its use. ${ }^{4}$ Nonetheless, in patients aged 75 years or more with combined comorbidities of obesity, left ventricular dysfunction, COPD, diabetes mellitus, and combined procedures in which long-term survival benefits of arterial revascularization are questionable, ${ }^{27-29}$ the NT SVG provides an excellent alternative.

During the study period, 2003 to 2008, a LITA graft was planned in approximately $95 \%$ of patients undergoing CABG. This is similar to a previous study in which $92.4 \%$ of LITA use was reported. ${ }^{30}$ The patients who received a planned SVG to the LAD were significantly older, with a lower ejection fraction, higher risk scores, and more combined procedures.

The second important finding, in contrast to other conduits, is that the patency of the NT SVGs to LAD and non-LAD targets was similar and high. The analysis, according to Fleming ${ }^{21}$ and Christensen, ${ }^{22}$ shows CIs within the margins of equivalence (Figure 4). This indicates that the target vessel size, the vessel quality, and the degree of stenosis have little or no effect on NT SVG performance, in contrast to arterial grafts. ${ }^{31}$ This may be due to the fact that undamaged or minimally manipulated NT SVGs anastomosed to different target vessels possess a greater ability to positively or negatively remodel, either increasing or decreasing in size according to flow demand. ${ }^{32}$ These findings are consistent with the results of our previous, randomized study in which patency rates of NT conduits were independent of target vessel size and quality and conduit flow rates. ${ }^{15}$ Even saphenous veins that were judged to be of a lower quality had an excellent patency rate when harvested by the NT technique.

Furthermore, there was no significant difference in the patency of single and sequential grafts. This last feature may not be due to the target vessel runoff but to the surrounding tissue that remains intact in NT grafts and acts as a biological, external stent protecting the long sequential grafts from kinking and reducing the potential for technical error. In the present study, $94.3 \%$ of the sequential anastomoses were patent.

If the NT SVG is a good alternative for the LAD, it could be considered more often as the second choice for any conduit in CABG. ${ }^{33}$ The follow-up is not yet long term, but at 6 years the results are good. There has been an increasing promotion of extensive arterial use $^{7}$ based on patency studies. This recommendation is most reasonable given the poor quality of conventionally harvested saphenous veins. However, NT SVGs have a significantly better quality, making the recommendation less compelling.

Even if extensive arterial revascularization is performed, SVGs still account for the majority of conduits used in most centers. ${ }^{34}$ This is due to numerous advantages of using the saphenous vein, including ease of access and manipulation, sufficient length for grafting, and short harvesting time. Clinical factors also may suggest that prolonged conduit longevity is not always the primary concern. Older age, female sex, left ventricular dysfunction, smoking, obesity, and diabetes are some of the factors that negatively affect survival. ${ }^{27,29}$ Consequently, the benefits of extensive arterial revascularization in CABG can be short-lived in these patients. This concept is even more important given that the age and comorbidities of the population undergoing CABG are increasing. ${ }^{35}$ Could the results of the present study, together with our previous studies, provide useful 
preliminary data for a large randomized trial to compare LITA-LAD with NT SVG-LAD outcomes?

\section{Study Limitations}

This is a small observational cohort trial, which potentially exposes it to selection bias. The 71 patients who were not included in the follow-up were older and had a higher rate of some comorbidities at baseline. Our analysis of a possible selection bias where the influence of age and euroSCORE was estimated for those patients available at the clinical evaluation gives us reasons to believe that selection bias is not likely a major limitation. We agree that a higher number of patients at follow-up would have strengthened our results, especially in giving it a broader basis for generalization of the outcome, and the $20.2 \%$ death rate is a limitation in this study.

\section{CONCLUSIONS}

In elderly patients with multiple comorbidities, the NT SVG represents an encouraging alternative conduit for bypassing the LAD in CABG. The equivalent high patency, to both LAD and non-LAD targets, is an outstanding feature of the NT SVG.

\section{Conflict of Interest Statement}

Authors have nothing to disclose with regard to commercial support.

The authors thank the staff at the Department of Cardiothoracic and Vascular Surgery and the Department of Radiology, Örebro University Hospital, for their assistance.

\section{References}

1. World Health Organization. The top 10 causes of death. World Health Statistics 2012. Available at: http://www.who.int/mediacentre/factsheets/fs310/en/. Accessed April 12, 2017

2. Head SJ, Kieser TM, Falk V, Huysmans HA, Kappetein AP. Coronary artery bypass grafting: Part 1 -the evolution over the first 50 years. Eur Heart J. 2013;34:2862-72.

3. Kolh P, Windecker S, Alfonso F, Collet JP, Cremer J, Falk V, et al. 2014 ESC/ EACTS Guidelines on myocardial revascularization. Eur J Cardiothorac Surg. 2014;46:517-92.

4. Hillis LD, Smith PK, Anderson JL, Bittl JA, Bridges CR, Byrne JG, et al. 2011 $\mathrm{ACCF} / \mathrm{AHA}$ Guideline for Coronary Artery Bypass Graft Surgery: a report of the American College of Cardiology Foundation/American Heart Association Task Force on Practice Guidelines. Circulation. 2011;124:e652-735.

5. Benedetto U, Amrani M, Bahrami T, Gaer J, De Robertis F, Smith RD, et al. Survival probability loss from percutaneous coronary intervention compared with coronary artery bypass grafting across age groups. J Thorac Cardiovasc Surg. 2015;149:479-84.e3.

6. Fitzgibbon GM, Kafka HP, Leach AJ, Keon WJ, Hooper GD, Burton JR. Coronary bypass graft fate and patient outcome: angiographic follow-up of 5065 grafts related to survival and reoperation in 1388 patients during 25 years. $J$ Am Coll Cardiol. 1996;28:616-26.

7. Aldea GS, Bakaeen FG, Pal J, Fremes S, Head SJ, Sabik J, et al. The Society of Thoracic Surgeons Clinical Practice Guidelines on arterial conduits for coronary artery bypass grafting. Ann Thorac Surg. 2016;101:801-9.

8. Loop FD, Lytle BW, Cosgrove DM, Stewart RW, Goormastic M, Williams GW, et al. Influence of the internal-mammary-artery graft on 10-year survival and other cardiac events. $N$ Engl J Med. 1986;314:1-6.
9. ElBardissi AW, Aranki SF, Sheng S, O’Brien SM, Greenberg CC, Gammie JS. Trends in isolated coronary artery bypass grafting: an analysis of the Society of Thoracic Surgeons adult cardiac surgery database. J Thorac Cardiovasc Surg. 2012;143:273-81.

10. Li FD, Eagle S, Brophy C, Hocking KM, Osgood M, Komalavilas P, et al. Pressure control during preparation of saphenous veins. JAMA Surg. 2014;149: 655-62.

11. Harskamp RE, Lopes RD, Baisden CE, de Winter RJ, Alexander JH. Saphenous vein graft failure after coronary artery bypass surgery: pathophysiology, management, and future directions. Ann Surg. 2013;257:824-33.

12. Souza D. A new no-touch preparation technique. Technical notes. Scand $J$ Thorac Cardiovasc Surg. 1996;30:41-4.

13. Souza DS, Dashwood MR, Tsui JC, Filbey D, Bodin L, Johansson B, et al Improved patency in vein grafts harvested with surrounding tissue: results of a randomized study using three harvesting techniques. Ann Thorac Surg. 2002; 73:1189-95

14. Souza DS, Johansson B, Bojö L, Karlsson R, Geijer H, Filbey D, et al Harvesting the saphenous vein with surrounding tissue for CABG provides long-term graft patency comparable to the left internal thoracic artery: results of a randomized longitudinal trial. J Thorac Cardiovasc Surg. 2006; 132:373-8.

15. Samano N, Geijer H, Liden M, Fremes S, Bodin L, Souza D. The no-touch saphenous vein for coronary artery bypass grafting maintains a patency, after 16 years, comparable to the left internal thoracic artery: a randomized trial. J Thorac Cardiovasc Surg. 2015;150:880-8.

16. Johansson B, Samano N, Souza D, Bodin L, Filbey D, Mannion JD, et al. The notouch vein graft for coronary artery bypass surgery preserves the left ventricular ejection fraction at 16 years postoperatively: long-term data from a longitudinal randomised trial. Open Heart. 2015;2:e000204.

17. Johansson BL, Souza DS, Bodin L, Filbey D, Bojo L. No touch vein harvesting technique for CABG improves the long-term clinical outcome. Scand Cardiovasc J. 2009; 43:63-8.

18. Boyko EJ. Observational research-opportunities and limitations. J Diabetes Complications. 2013;27:642-8.

19. Hamon M, Lepage O, Malagutti P, Riddell JW, Morello R, Agostini D, et al. Diagnostic performance of 16- and 64-section spiral CT for coronary artery bypass graft assessment: meta-analysis. Radiology. 2008; 247:679-86.

20. Rabe-Hesketh S, Skrondal A. Multilevel and Longitudinal Modeling Using Stata: Volume I: Continuous Responses \& Volume II: Categorical Responses, Counts, and Survival. College Station, TX: StataCorp LP; 2012.

21. Fleming TR. Design and interpretation of equivalence trials. Am Heart J. 2000; 139:S171-6.

22. Christensen E. Methodology of superiority vs equivalence trials and non inferiority trials. J Hepatol. 2007;46:947-54.

23. Harskamp RE, Alexander JH, Ferguson TB Jr, Hager R, Mack MJ, Englum B et al. Frequency and predictors of internal mammary artery graft failure and subsequent clinical outcomes: insights from the PREVENT IV Trial. Circulation. 2016;133:131-8

24. Goldman S, Zadina K, Moritz T, Ovitt T, Sethi G, Copeland JG, et al. Long-term patency of saphenous vein and left internal mammary artery grafts after coronary artery bypass surgery: results from a Department of Veterans Affairs Cooperative Study. J Am Coll Cardiol. 2004;44:2149-56.

25. Tatoulis J, Buxton BF, Fuller JA. Patencies of 2127 arterial to coronary conduits over 15 years. Ann Thorac Surg. 2004;77:93-101.

26. Cameron A, Davis KB, Green G, Schaff HV. Coronary bypass surgery with internal-thoracic-artery grafts-effects on survival over a 15 -year period. $N$ Engl J Med. 1996;334:216-9.

27. Weintraub WS, Clements SD, Crisco LV-T, Guyton RA, Craver JM, Jones EL, et al. Twenty-year survival after coronary artery surgery: an institutional perspective from Emory University. Circulation. 2003;107:1271-7.

28. Benedetto U, Codispoti M. Age cutoff for the loss of survival benefit from use of radial artery in coronary artery bypass grafting. J Thorac Cardiovasc Surg. 2013; 146:1078-85.

29. Myers WO, Blackstone EH, Davis K, Foster ED, Kaiser GC. CASS registry: long term surgical survival. J Am Coll Cardiol. 1999;33:488-98.

30. Tabata M, Grab JD, Khalpey Z, Edwards FH, O'Brien SM, Cohn LH, et al Prevalence and variability of internal mammary artery graft use in contemporary multivessel coronary artery bypass graft surgery: analysis of the Society of Thoracic Surgeons National Cardiac Database. Circulation. 2009 120:935-40 
31. Sabik JF, Lytle BW, Blackstone EH, Houghtaling PL, Cosgrove DM. Comparison of saphenous vein and internal thoracic artery graft patency by coronary system. Ann Thorac Surg. 2005;79:544-51.

32. Deb S, Souza DSR, Fremes SE. Composite vein grafting: is it a "Y's" decision? J Thorac Cardiovasc Surg. 2015;149:494-5.

33. Dreifaldt M, Mannion JD, Bodin L, Olsson H, Zagozdzon L, Souza D. The no-touch saphenous vein as the preferred second conduit for coronary artery bypass grafting. Ann Thorac Surg. 2013;96:105-11.

34. Bello SO, Peng EW, Sarkar PK. Conduits for coronary artery bypass surgery: the quest for second best. J Cardiovasc Med (Hagerstown). 2011;12:411-21.
35. Cornwell LD, Omer S, Rosengart T, Holman WL, Bakaeen FG. Changes over time in risk profiles of patients who undergo coronary artery bypass graft surgery: the Veterans Affairs Surgical Quality Improvement Program (VASQIP). JAMA Surg. 2015;150:308-15.

Key Words: bypass graft, computed tomography angiography, coronary artery bypass grafting, left internal thoracic artery, no-touch harvesting technique, patency, saphenous vein

Readers who found these articles interesting may also like to read the following papers found in recent and future issues of our sister publications, Seminars in Thoracic and Cardiovascular Surgery and Operative Techniques in Thoracic and Cardiovascular Surgery!

\section{Acquired: Coronary}

ORIGINAL SUBMISSION: Open Aortic Arch Reconstruction After Coronary Artery Bypass Surgery: Worth the Effort? Eduard Quintana. Semin Thoracic Surg 2016:26-35.

Editorial Commentary: Risky Business or Acceptable Risk? Open Arch Repair After Coronary Artery Bypass Surgery. Joseph S. Coselli. Semin Thoracic Surg 2016:36-37.

NEW AND VIEWS: Training in Coronary Artery Bypass Surgery: Tips and Tricks of the Trade. Giuseppe Maria Raffa. Semin Thoracic Surg 2017: In press.

ORIGINAL SUBMISSION: How Safe Is it to Train Residents to Perform Coronary Surgery With Multiple Arterial Grafting? Nineteen Years of Training at a Single Institution. Umberto Benedetto. Semin Thoracic Surg 2017: In press.

Editorial Commentary: Hey! Teacher! Leave Them Kids Alone! Joshua L. Hermsen. Semin Thoracic Surg 2017: In press.

ORIGINAL SUBMISSION: Off-Pump Coronary Artery Bypass Grafting. Bobby Yanagawa. Oper Tech Thorac Cardiovasc 2016:2-19. ORIGINAL SUBMISSION: Total Arterial Revascularization. Silvana Marasco. Oper Tech Thorac Cardiovasc 2016: 20-30. 
TABLE E1. Patency of saphenous vein grafts by target coronary arteries and number of years between surgery and angiographic assessment

\begin{tabular}{lccccc} 
No. of years between surgery & \multicolumn{5}{c}{ SVG patency to different target coronary arteries } \\
\cline { 2 - 6 } and angiographic assessment & LAD & Diagonal artery & Marginal artery & Right coronary artery & All non-LAD targets \\
\hline 4 & $88.9 \%(\mathrm{n}=9)$ & $83.3 \%(\mathrm{n}=6)$ & $100.0 \%(\mathrm{n}=12)$ & $100.0 \%(\mathrm{n}=4)$ & $95.5 \%(\mathrm{n}=22)$ \\
5 & $97.0 \%(\mathrm{n}=33)$ & $100.0 \%(\mathrm{n}=21)$ & $96.9 \%(\mathrm{n}=32)$ & $91.7 \%(\mathrm{n}=24)$ & $96.1 \%(\mathrm{n}=77)$ \\
6 & $96.9 \%(\mathrm{n}=32)$ & $100.0 \%(\mathrm{n}=14)$ & $90.6 \%(\mathrm{n}=32)$ & $93.4 \%(\mathrm{n}=16)$ & $93.6 \%(\mathrm{n}=62)$ \\
7 & $90.9 \%(\mathrm{n}=11)$ & $100.0 \%(\mathrm{n}=5)$ & $90.9 \%(\mathrm{n}=11)$ & $100.0 \%(\mathrm{n}=5)$ & $95.2 \%(\mathrm{n}=21)$ \\
$8-9 *$ & $100.0 \%(\mathrm{n}=6)$ & $100.0 \%(\mathrm{n}=4)$ & $50.0 \%(\mathrm{n}=6)$ & $100.0 \%(\mathrm{n}=3)$ & $76.9 \%(\mathrm{n}=13)$ \\
All & $95.6 \%(\mathrm{n}=91)$ & $98.0 \%(\mathrm{n}=50)$ & $91.4 \%(\mathrm{n}=93)$ & $94.23 \%(\mathrm{n}=52)$ & $93.8 \%(\mathrm{n}=195)$ \\
\hline
\end{tabular}

SVG, Saphenous vein graft; $L A D$, left anterior descending. *Because of few cases with 9 years, the 8 and 9 years are combined in 1 category.

TABLE E2. Trials reporting patency of left internal thoracic artery grafts to the left anterior descending artery and saphenous vein grafts to the left anterior descending at 1 to 16 years postoperatively

\begin{tabular}{|c|c|c|c|c|c|c|}
\hline Author(s), years of publication, journal & Study design & $\begin{array}{c}\text { Follow-up } \\
(\mathbf{y})\end{array}$ & $\begin{array}{c}\text { LITA-LAD } \\
\text { (n) }\end{array}$ & $\begin{array}{c}\text { Patency } \\
(\%)\end{array}$ & $\begin{array}{c}\text { SVG-LAD } \\
\text { (n) }\end{array}$ & $\begin{array}{c}\text { Patency } \\
(\%)\end{array}$ \\
\hline Bakaeen and colleagues, 2012, Ann Thorac Surg ${ }^{\mathrm{E} 1}$ & Nonrandomized & 1 & 454 & 96.2 & - & - \\
\hline Harskamp and colleagues, 2015, Circulation $^{\mathrm{E} 2}$ & Randomized & 1.3 & 1539 & 91.4 & - & - \\
\hline Lytle and colleagues, $1985, J$ Thorac Cardiovasc Surg ${ }^{\mathrm{E} 3}$ & Nonrandomized & 1.3 & 115 & 96 & 261 & 88 \\
\hline Souza and colleagues, 2002, Ann Thorac Surg ${ }^{\mathrm{E} 4}$ & Randomized & 1.5 & 83 & 93 & - & - \\
\hline Khot and colleagues, 2004, Circulation $^{\mathrm{E} 5}$ & Nonrandomized & 1.6 & 249 & 90.8 & 44 & 65.9 \\
\hline Bical and colleagues, 1996, Eur J Cardiothorac Surg ${ }^{\mathrm{E} 6}$ & Nonrandomized & 1.8 & 36 & 94.4 & - & - \\
\hline Dreifaldt and colleagues, 2013, Ann Thorac Surg ${ }^{\mathrm{E} 7}$ & Randomized & 3 & 96 & 92.7 & - & - \\
\hline Loop and colleagues, 1986, $N$ Engl J Med $\mathrm{M}^{\mathrm{E} 8}$ & Nonrandomized & 3 & 855 & 96 & 1445 & $81.1 \S$ \\
\hline Singh and colleagues, 1983, Br Heart $J^{\mathrm{E} 9}$ & Nonrandomized & 3.6 & 33 & 97 & 43 & 63 \\
\hline Gaudino and colleagues, 2005, Circulation ${ }^{\mathrm{E} 10}$ & Randomized & 4.3 & 120 & 95.8 & - & - \\
\hline Tranbaugh and colleagues, 2012, Circulation ${ }^{\mathrm{E} 11}$ & Nonrandomized & 5 & $287^{*}$ & 85 & $272 \dagger$ & 60 \\
\hline Tatoulis and colleagues, 2011, Curr Opin Cardiol $^{\mathrm{E} 12}$ & Nonrandomized & 5 & 1273 & 98.4 & - & - \\
\hline Samano and colleagues, 2016, present study & Nonrandomized & 6 & - & - & $51 \|$ & 98 \\
\hline Goldman and colleagues, 2004, J Am Coll Cardiol ${ }^{\mathrm{E} 13}$ & Nonrandomized & 6 & 295 & 87.5 & 259 & 75 \\
\hline Tatoulis and colleagues, 2004, Ann Thorac Surg ${ }^{\mathrm{E} 14}$ & Nonrandomized & 6.6 & 1165 & 97.1 & 1210 & $60.2 \ddagger$ \\
\hline Shah and colleagues, 2004, Eur J Cardiothorac Surg ${ }^{\mathrm{E} 15}$ & Nonrandomized & 6.6 & 1193 & 97.2 & - & - \\
\hline Lytle and colleagues, $1985, J$ Thorac Cardiovasc Surg ${ }^{\mathrm{E} 3}$ & Nonrandomized & 7.3 & 115 & 94 & 261 & 49 \\
\hline Dion and colleagues, 2000, Eur J Cardiothorac Surg ${ }^{\mathrm{E} 16}$ & Nonrandomized & 7.5 & 273 & 96.7 & - & - \\
\hline Souza and colleagues, 2006, J Thorac Cardiovasc Surg ${ }^{\mathrm{E} 17}$ & Randomized & 8.5 & 68 & 90 & - & - \\
\hline Zeff and colleagues, 1988, Ann Thorac Surg ${ }^{\mathrm{E} 18}$ & Randomized & 8.8 & 38 & 94.6 & 38 & 76.3 \\
\hline Tatoulis and colleagues, 2011, Curr Opin Cardiol $^{\mathrm{E} 12}$ & Nonrandomized & 10 & 626 & 96.5 & - & - \\
\hline Tatoulis and colleagues, 2004, Ann Thorac Surg ${ }^{\mathrm{E} 14}$ & Nonrandomized & 10 & - & 97 & - & - \\
\hline Goldman and colleagues, 2004, J Am Coll Cardiol $^{\mathrm{E} 13}$ & Nonrandomized & 10 & 85 & 85 & 75 & 69 \\
\hline Grondin and colleagues, 1984, Circulation $^{\mathrm{E} 19}$ & Nonrandomized & 10 & 16 & 93.7 & 63 & 77.8 \\
\hline Tatoulis and colleagues, 2004, Ann Thorac Surg ${ }^{\mathrm{E} 14}$ & Nonrandomized & 15 & - & 93 & - & - \\
\hline Samano and colleagues, 2015, J Thorac Cardiovasc Surg ${ }^{\mathrm{E} 20}$ & Randomized & 16 & 48 & 88 & - & - \\
\hline
\end{tabular}

Some studies are mentioned more than once because of several follow-up periods within the same study. LITA, Left internal thoracic artery; LAD, left anterior descending artery; $S V G$, saphenous vein graft. *LITA to LAD/diagonal arteries. †SVG to LAD/diagonal arteries. †Mean follow-up 8.7 years. §Mean follow-up 3.3 years. ||Single NT SVG. 
TABLE E3. Distribution of saphenous vein graft patency by number of distal anastomoses and target coronary arteries stratified for patient's age and European System for Cardiac Operative Risk Evaluation

\begin{tabular}{|c|c|c|c|c|c|c|}
\hline \multirow[b]{2}{*}{$\begin{array}{l}\text { Target coronary } \\
\text { arteries (n) }\end{array}$} & \multirow{2}{*}{$\begin{array}{c}\text { SVG patency } \\
\text { patent/total } \\
(\%)\end{array}$} & \multicolumn{5}{|c|}{ Difference SVG-LAD, \% $(95 \%$ CI $)$} \\
\hline & & $\begin{array}{c}\text { All } \\
(n=286)\end{array}$ & $\begin{array}{c}\text { Age }<71 \text { y } \\
(n=139)\end{array}$ & $\begin{array}{c}\text { Age } \geq 71 y \\
(n=147)\end{array}$ & $\begin{array}{c}\text { euroSCORE } \leq 5 \\
(\mathbf{n}=125)\end{array}$ & $\begin{array}{c}\text { euroSCORE }>5 \\
(n=161)\end{array}$ \\
\hline $\operatorname{LAD}(\mathrm{n}=91)$ & $87 / 91(95.6)$ & (Reference) & (Reference) & (Reference) & (Reference) & (Reference) \\
\hline Diagonal artery $(\mathrm{n}=50)$ & $49 / 50(98.0)$ & $-0.2(-4.2$ to 3.6$)$ & $2.0(-4.8$ to 8.7$)$ & $-3.5(-6.7$ to -0.3$)$ & $0.9(-7.4$ to 9.3$)$ & $-2.5(-4.9$ to 0.2$)$ \\
\hline Marginal artery $(n=93)$ & $85 / 93(91.4)$ & $-4.7(-11.4$ to 2.0$)$ & $-4.5(-13.5$ to 4.5$)$ & $-4.5(-1440$ to 5.4$)$ & $-6.9(-17.4$ to 3.6$)$ & $-2.4(-11.0$ to 6.2$)$ \\
\hline $\begin{array}{l}\text { Right coronary artery } \\
\qquad(\mathrm{n}=52)\end{array}$ & $49 / 52(94.2)$ & $-1.2(-8.2$ to 5.8$)$ & $-1.1(-12.2$ to 9.9$)$ & $-1.3(-10.0$ to 7.4$)$ & $0.0(-12.0$ to 12.0$)$ & $-1.5(-9.7$ to 6.8$)$ \\
\hline $\begin{array}{l}\text { All non-LAD coronary } \\
\text { arteries }(\mathrm{n}=195)\end{array}$ & 183/195 (93.9) & $-2.6(-7.4$ to 2.1$)$ & $-1.8(-9.0$ to 5.4$)$ & $-3.4(-9.7$ to 3.0$)$ & $-3.4(-11.8$ to 4.9$)$ & $-2.1(-7.8$ to 3.4$)$ \\
\hline
\end{tabular}

Analysis by generalized linear latent and mixed models (see text). Time from surgery to angiographic assessment is included in the estimation model. Time (in years) from surgery to angiographic assessment had a negative coefficient $-0.02(95 \% \mathrm{CI},-0.06$ to 0.02$)$ indicating lower patency for a longer period of time, but not reaching statistical significance $(P=.27)$. SVG, Saphenous vein graft; euroSCORE, European System for Cardiac Operative Risk Evaluation; LAD, left anterior descending; $C I$, confidence interval. 


\section{E-References}

E1. Bakaeen FG, Sethi G, Wagner TH, Kelly R, Lee K, Upadhyay A, et al. Coronary artery bypass graft patency: residents versus attending surgeons. Ann Thorac Surg. 2012;94:482-8.

E2. Harskamp RE, Alexander JH, Ferguson TB Jr, Hager R, Mack MJ, Englum B, et al. Frequency and predictors of internal mammary artery graft failure and subsequent clinical outcomes: insights from the PREVENT IV Trial. Circulation. 2016;133:131-8.

E3. Lytle BW, Loop FD, Cosgrove DM, Ratliff NB, Easley K, Taylor PC. Long-term (5 to 12 years) serial studies of internal mammary artery and saphenous vein coronary bypass grafts. J Thorac Cardiovasc Surg. 1985;89: 248-58.

E4. Souza DS, Dashwood MR, Tsui JC, Filbey D, Bodin L, Johansson B, et al. Improved patency in vein grafts harvested with surrounding tissue: results of a randomized study using three harvesting techniques. Ann Thorac Surg. 2002;73:1189-95.

E5. Khot UN, Friedman DT, Pettersson G, Smedira NG, Li J, Ellis SG. Radial artery bypass grafts have an increased occurrence of angiographically severe stenosis and occlusion compared with left internal mammary arteries and saphenous vein grafts. Circulation. 2004;109:2086-91.

E6. Bical O, Braunberger E, Fischer M, Robinault J, Foiret JC, Fromes Y, et al. Bilateral skeletonized mammary artery grafting: experience with 560 consecutive patients. Eur J Cardiothorac Surg. 1996;10:971-5.

E7. Dreifaldt M, Mannion JD, Bodin L, Olsson H, Zagozdzon L, Souza D. The notouch saphenous vein as the preferred second conduit for coronary artery bypass grafting. Ann Thorac Surg. 2013;96:105-11.

E8. Loop FD, Lytle BW, Cosgrove DM, Stewart RW, Goormastic M, Williams GW, et al. Influence of the internal-mammary-artery graft on 10-year survival and other cardiac events. N Engl J Med. 1986;314:1-6.

E9. Singh RN, Sosa JA, Green GE. Internal mammary artery versus saphenous vein graft. Comparative performance in patients with combined revascularisation. Br Heart J. 1983;50:48-58.

E10. Gaudino M, Cellini C, Pragliola C, Trani C, Burzotta F, Schiavoni G, et al. Arterial versus venous bypass grafts in patients with in-stent restenosis. Circulation. 2005;112(9 Suppl):I265-9.
E11. Tranbaugh RF, Dimitrova KR, Friedmann P, Geller CM, Harris LJ, Stelzer P, et al. Coronary artery bypass grafting using the radial artery: clinical outcomes, patency, and need for reintervention. Circulation. 2012;126(11 Suppl 1): S170-5.

E12. Tatoulis J, Buxton BF, Fuller JA. The right internal thoracic artery: is it underutilized? Curr Opin Cardiol. 2011;26:528-35.

E13. Goldman S, Zadina K, Moritz T, Ovitt T, Sethi G, Copeland JG, et al. Long-term patency of saphenous vein and left internal mammary artery grafts after coronary artery bypass surgery: results from a Department of Veterans Affairs Cooperative Study. J Am Coll Cardiol. 2004;44:2149-56.

E14. Tatoulis J, Buxton BF, Fuller JA. Patencies of 2127 arterial to coronary conduits over 15 years. Ann Thorac Surg. 2004;77:93-101

E15. Shah PJ, Durairaj M, Gordon I, Fuller J, Rosalion A, Seevanayagam S, et al Factors affecting patency of internal thoracic artery graft: clinical and angiographic study in 1434 symptomatic patients operated between 1982 and 2002. Eur J Cardiothorac Surg. 2004;26:118-24.

E16. Dion R, Glineur D, Derouck D, Verhelst R, Noirhomme P, El Khoury G, et al Long-term clinical and angiographic follow-up of sequential internal thoracic artery grafting. Eur J Cardiothorac Surg. 2000;17:407-14.

E17. Souza DS, Johansson B, Bojö L, Karlsson R, Geijer H, Filbey D, et al. Harvesting the saphenous vein with surrounding tissue for $\mathrm{CABG}$ provides long-term graft patency comparable to the left internal thoracic artery: results of a randomized longitudinal trial. J Thorac Cardiovasc Surg. 2006;132:373-8.

E18. Zeff RH, Kongtahworn C, Iannone LA, Gordon DF, Brown TM, Phillips SJ, et al. Internal mammary artery versus saphenous vein graft to the left anterior descending coronary artery: prospective randomized study with 10-year follow-up. Ann Thorac Surg. 1988;45:533-6.

E19. Grondin CM, Campeau L, Lesperance J, Enjalbert M, Bourassa MG. Comparison of late changes in internal mammary artery and saphenous vein grafts in two consecutive series of patients 10 years after operation. Circulation. 1984; 70(3 Pt 2):I208-12.

E20. Samano N, Geijer H, Liden M, Fremes S, Bodin L, Souza D. The no-touch saphenous vein for coronary artery bypass grafting maintains a patency, after 16 years, comparable to the left internal thoracic artery: a randomized trial. $J$ Thorac Cardiovasc Surg. 2015;150:880-8. 